\title{
Reflections in the Waves: What Interreligious Studies can Learn from Women's Movements in the U.S.
}

\author{
Rachel S. Mikva
}

\begin{abstract}
In this chapter I trace the development of interreligious studies and engagement in the United States by comparing it with the "waves" of women's movements, and then use those insights to reflect on interreligious education at Chicago Theological Seminary and beyond.
\end{abstract}

As colleges, universities, and seminaries innovate programs in interreligious studies while the academic field is just taking shape, where do we look for theoretical and pedagogical models? Although we can trace the modern study of Religionsgeschichte ("history of religions") to the nineteenth century and examine the field of comparative religion that emanated from it, these academic foci do not necessarily provide the best foundation for our work. As Paul Hedges points out, such approaches generally seek an ostensibly "objective historical or phenomenological account of similarities or points of meeting between religious traditions," whereas interreligious studies "is more expressly focused on the dynamic encounter between religious traditions and persons." ${ }^{2}$ When we recognize also the critical mix of theory and praxis within interreligious studies, the commitment to seek understanding across lines of difference, ${ }^{3}$ the

1 This chapter is adapted from Rachel S. Mikva, "Reflections in the Waves: What Interreligious Studies Can Learn from the Evolutions of Women's Movements in the United States," Journal of Ecumenical Studies 53:4 (Fall 2018): 461-82; and from a panel presentation, "Religious Pluralism and Feminist/Womanist/Mujerista Theologies," American Academy of Religion Annual Meeting, 2015 .

2 Paul Hedges, "Interreligious Studies," in Anne Runehov and Lluis Oviedo, eds., Encyclopedia of Sciences and Religions (Dordrecht: Springer Netherlands, 2013), 1077.

3 The phrase draws from Diana Eck's definition of religious pluralism; see The Pluralism Project, Harvard University, accessed January 10, 2019, http://www.pluralism.org/what-is-pluralism/.

(C) RACHEL S. MIKVA, 2020 | DOI:10.1163/9789004420045_009

This is an open access chapter distributed under the terms of the CC BY-NC-ND 4po License. 
intersectional and interdisciplinary complexity, the contextual urgency of the issues, and the particular challenges that arise, we may discover it is more fruitful to examine the development of a field that shares all these qualities, such as women's studies (and now gender studies).

To explore the potential of this association, Part 1 outlines "waves" within women's movements and identifies parallels that illuminate the interreligious project, with its headwaters in Religionsgeschichte and its unique directional flows. This broad sketch is a heuristic framework, leaving aside for now much of the complexity that typifies both gender and interreligious studies. ${ }^{4} \mathrm{I}$ employ an historical perspective but I do not chart the waves by decade; one wave does not end precisely as the next one begins. If we think of waves as forces within the ocean that have mass and momentum before they arrive on shore, and which continue to move in the waters after defining their particular outline in the sand, and if we recall that there is never only one wave moving at a time - then we can examine the sequential but not separate waves that emphasize (1) equality, (2) difference, (3) diversity, and (4) intersubjectivity.

This lens sharpens our view of the learning curve for interreligious studies and engagement, and illuminates some of its growing edges. I discuss in Part 2 how the theoretical framework informs the pedagogy at Chicago Theological Seminary, and then draw from this one context to discern broader implications for the emerging field.

Two qualifications are in order. First, this examination of feminism's waves delineates a Western, especially American-focused, analysis. Although it is a limited perspective on global questions of gender justice, it suits this discussion of interreligious studies, which has a similar geographical/cultural focus. Second, there is ongoing debate about the influences and most essential qualities of each wave in women's movements; the current study selects elements that provide the most salient comparisons.

Part 1: The Waves

\subsection{Equality}

The modern women's movement began with a fight for equality. ${ }^{5}$ In the nineteenth and early twentieth centuries, women campaigned for suffrage and for

4 Many works within gender studies both utilize and problematize the "wave" framework. See Cathryn Bailey, "Making Waves and Drawing Lines: The Politics of Defining the Vicissitudes of Feminism," Hypatia 12, no. 3 (June 1997): 17-28; Stacy Gillis, Gillian Howie, and Rebecca Munford, eds., Third Wave Feminism: A Critical Exploration, 2nd ed. (New York: Palgrave Macmillan, 2007).

5 The beginning of the "first wave" is often attributed to the Seneca Falls Women's Rights Convention in 1848, organized by Lucretia Mott, Elizabeth Cady Stanton, and others, with 
labor protections; they demanded the right to own property, enter restricted professions, serve on juries, divorce their husbands, and receive custody of their children. They sought freedom to speak in the public square and to enter male domains of education and leadership.

Yet the theory underlying this drive for equality addressed human nature as androgynous, and thus the standard was still a male one. Women fought to vote and to attend school because, they argued, they could be as rational as men. Working class women fought for their rights as part of the universal (male) proletariat. Even Sojourner Truth's phenomenal speech, "Ain't I A Woman?" in which she insisted that "woman" did not mean "white woman" and challenged the social construction of women as delicate flowers who need male protection, contested that narrative by comparing her labor and her toughness to that of a man. ${ }^{6}$ Equality became sameness, an attitude that helped to sustain patriarchal privilege at the same time that women's movements sought to challenge it. ${ }^{7}$

There are numerous parallels with the development of interreligious engagement during the same period. Christian privilege pervaded multiple aspects of society: in blue laws that restricted commercial enterprises on Sundays, in religious tests for state and local public office, in the Protestant tone of public education, and in repeated calls to amend the Constitution to explicitly declare the United States a Christian nation. ${ }^{8}$ Despite the First Amendment's protection of religious freedom, adherents of minority traditions in the United States were often engaged in struggles for equality.

Before the Civil Rights movement, for example, Jews were excluded from social clubs and hotels; they could not buy property in certain areas or purchase insurance for their businesses. They were regularly denounced in publications of the era and considered suspect as witnesses in judicial proceedings. Quotas were imposed on university admissions and, after the 1924 Immigration Act, on admission to the country, disguised as limits based on countries of origin. ${ }^{9}$ Significant communal energy was devoted to combating such

its impetus assigned to the abolitionist movement. An alternative "first wave" is Mary Wollstonecraft's 1793 work, A Vindication of the Rights of Women (repr., New York: A. J. Matsell, 1833).

6 Ohio Women's Rights Convention held in Akron, 1851: Sojourner Truth, "Ain't I a Woman?" accessed January 10, 2019, https://sourcebooks.fordham.edu/mod/sojtruth-woman.asp.

7 See Carole Pateman, The Sexual Contract (Cambridge, MA: Polity Press, 1988); and Carol Gilligan, In a Different Voice (Cambridge, MA: Harvard University Press, 1982).

8 Naomi Cohen, Jews in Christian America: The Pursuit of Religious Equality (New York: Oxford University Press, 1992), 65-92. See also Warren Blumenfeld, Khyati Joshi, and Ellen Fairchild, eds., Investigating Christian Privilege and Religious Oppression in the United States (Rotterdam: Sense Publishers, 2008).

9 Leonard Dinnerstein, Antisemitism in America (New York: Oxford University Press, 1994). 
discrimination; for example, the Anti-Defamation League was founded in 1913 "to stop the defamation of the Jewish people and to secure justice and fair treatment to all."10 In 1923 the Federal Council of Churches established a committee to reduce anti-Jewish and anti-Catholic prejudice, as an extension of its ecumenical commitments.

A key strategy in the fight for equality was to emphasize similarity with mainline Protestantism, the dominant faith of the nation. Many Reform synagogues moved their primary worship to Sunday, and increasingly modeled the service in a Protestant style. ${ }^{11}$ The movement's Pittsburgh Platform, ratified in 1885, emphasized Judaism's "universal" teachings of monotheism and minimized Jewish particularity, rejecting all rituals that "are not adapted to the views and habits of modern civilization."12

The birth of the modern interfaith movement is sometimes traced to the 1893 World's Parliament of Religions, convened parallel to the Columbian Exposition in Chicago; it was an axial event in shaping attitudes toward religious diversity. ${ }^{13}$ As the first time that many Americans came into contact with Eastern traditions, there was a commitment to portray "the substantial unity of many religions in the good deeds of the Religious Life."14 Yet this universal vision of common ground was self-consciously located in Christian territory. John Henry Barrows, president of the Parliament, was sincere in his desire to examine the shared principles of the world's religions, but his concept of universal was essentially an expansive Christianity. He wrote of the proceedings, "The Christian spirit pervaded the conference from first to last. Christ's prayer was daily used. His name was always spoken with reverence. His doctrine was preached by a hundred Christians and by lips other than Christian. The Parliament ended at Calvary."15

10 The Anti-Defamation League (ADL), accessed January 10, 2019, http://www.adl.org/ about-adl/.

11 This process began in Germany; see Michael Meyer, Response to Modernity: A History of the Reform Movement in Judaism (Detroit, IL: Wayne State University, 1995). "Reform Judaism: The Pittsburgh Platform," Jewish Virtual Library, accessed January 10, 2019, http://www.jewishvirtuallibrary.org/jsource/Judaism/pittsburgh_program.html. Subsequent platforms of the movement reclaimed numerous rituals and increasingly valued Jewish particularity; they can be understood within the second wave, which made more space for difference.

13 Eric J. Ziolkowski, ed., A Museum of Faiths: Histories and Legacies of the 1893 World's Parliament of Religions (New York: Oxford University Press, 1993), 3.

14 Charles Carroll Bonney, The World To-day: A Monthly Record of Human Progress, Vol. 3 (Chicago: World Review Company, 1902), 1501.

15 John Henry Barrows, ed., The World's Parliament of Religions (Chicago: Parliament Publishing Co., 1893), 2:1578. Other inequities were also evident; many African Americans criticized the Exposition (and the Parliament) for its nearly total exclusion of blacks from the list of speakers and from the shaping of American history: "Ida B. Wells: African 
Academic trends that followed in the Parliament's wake, such as the growth of the Chicago School, attempted to "dislodge ... the study of other religions from its missionary moorings and set it free as a discrete academic specialty."16 Yet Joachim Wach, putative founder of the school, reinforced Christianity as the norm against which other religions could be measured. He sought "to describe the landscape of world religions such that Christianity is the ultimate truth," and "felt that his normative project was leading toward the realization of a Christian telos that he thought already properly described the ultimate religious experience."17

Scholarship of the era may not have been subservient to Christian evangelical commitments, but it still advanced the cause. Religions were seen to have value to the extent that they paralleled the Christian norm. Monotheistic traditions fared relatively well in this light, but tribal religions were deemed primitive and Eastern practices were exoticized. Theology of religions meant Christian theology, and categories of study were Christian categories. ${ }^{18}$

Community-based interfaith efforts reflected these dynamics. Interreligious prayer modeled white mainstream Protestant worship, and dialogue emphasized sameness: Look at all we have in common! In 1965, the Second Vatican Council issued the declaration, Nostra Aetate, a paradigm-shattering statement of kinship with diverse religionists that expanded interreligious engagement exponentially. It too was based on similarity between the traditions:

In our time, when day by day mankind is being drawn closer together, and the ties between different peoples are becoming stronger, the Church examines more closely her relationship to non-Christian religions. In her task of promoting unity and love among men, indeed among nations, she considers above all in this declaration what men have in common and what draws them to fellowship. ${ }^{19}$

Americans at the World's Columbian Exhibition," Chicago Encyclopedia, accessed January 10, 2019, http://www.encyclopedia.chicagohistory.org/pages/1495.html.

16 Conrad Cherry, Hurrying Toward Zion (Bloomington, IN: Indiana University Press, 1995), 77 .

17 Charles S. Preston, "Wach, Radhakrishan, and Relativism," in Christian Wedemeyer and Wendy Doniger, eds., Hermeneutics, Politics and the History of Religions (New York: Oxford University Press, 2010), 94.

18 See Tomoko Masuzawa, The Invention of World Religions: Or, How European Universalism Was Preserved in the Language of Pluralism (Chicago: University of Chicago Press, 2005).

19 Pope Paul VI, Nostra Aetate, The Vatican, October 28, 1965, accessed January 10, 2019, www.vatican.va/archive/hist_councils/ii_vatican_council/documents/ vat-ii_decl_19651028_nostra-aetate_en.html. 
This became the grounds for equality. Such efforts bore fruit, but also sustained Christian privilege, leaving its normativity substantially unchallenged.

As in the evolving women's movements, the struggle for equality is not over. Atheists have a hard time getting elected to public office in the United States. Some religious individuals, especially Muslims, are targets of overt discrimination. Between 2010 and 2017, forty-three states introduced anti-Sharia legislation and twenty bills were enacted. The Trump administration has repeatedly attempted to ban foreign Muslims from entering the country, again trying to pass Constitutional muster by identifying "countries of origin" in order to obscure religious bias. Native Americans have endured a long history of court cases denying their First Amendment free exercise claims, and they continue to witness violation of their sacred lands (e.g., the Dakota Access Pipeline project that threatens ancient burial grounds and the water supply at the Standing Rock reservation). These are not acts of isolated individuals but represent broad-based social bias.

In the ongoing construction of interreligious studies and engagement, where nominal equality is a given, representation and voice emerge as key issues and there are always new battles on the horizon..$^{20}$ Secular humanism and other nonreligious lifestances ${ }^{21}$ are only beginning to be addressed in North American interreligious efforts because they are not sufficiently "like" the norm. This bias has had consequences for funding from campus spiritual life offices, invitations to the interfaith table, inclusion in textbooks and analyses. ${ }^{22}$ It is also powerfully reflected in the continuing inadequacy of the field to linguistically account for these lifestances other than by what they are noti.e., "nonreligious." New religious movements, individuals who identify with multiple traditions, those who identify as spiritual but not religious, and pagan or indigenous cultures are often still invisible in scholarly discussions and applied contexts. ${ }^{23}$

$20 \quad$ See Rachel Mikva, "Six Issues that Complicate Interreligious Studies and Engagement," in Eboo Patel, Jennifer Peace, and Noah Silverman, eds., Toward a Field of Interfaith Studies (Boston: Beacon Press, 2018), 124-36.

21 "Lifestance" (also "life stance") was coined to open up religious and interreligious discourse to include nonreligious perspectives around matters of ultimate concern: See Harry Stopes-Roe, "Humanism as a Life Stance," New Humanist 103, no. 2 (October 1988): 19-21. Although the term caught on more quickly in Europe than in North America, the recent expansion of interreligious studies to include secular humanism, atheism, etc. presses for similarly inclusive language.

22 Harvard University had a humanist chaplain in 1974, but this was highly unusual until recently.

23 See Grove Harris, "Pagan Involvement in the Interfaith Movement: Exclusions, Dualities and Contributions," Crosscurrents 55, no. 1 (Spring 2005): 66-76; Karla Suomala, "Complex 


\subsection{Difference}

A subsequent wave of feminist theory emphasized difference. Women recognized that it was not helpful to default to maleness as the norm, and began to take seriously the category of "woman." Theorists also looked at how sexual difference is socially constructed and symbolically fraught; for example, women's roles have been historically undervalued, and female qualities seen as undesirable, due to the enduring power of patriarchy. ${ }^{24}$ Eventually this wave washed into religious studies as well, even though there was tension between the fields. Lettie Cottin Pogrebin claims she often felt "like a double agent for two sacred causes, Judaism and feminism, neither of which necessarily believes the other deserves a place in heaven." ${ }^{25}$ Nonetheless, (mostly female) theologians grew sensitive to the impact of male imagery for God, of women's erasure from scriptural exegesis and religious history, and of religious authority used to preserve patriarchal structures. ${ }^{26}$

In the process, however, feminist efforts tended to essentialize "woman" as a singular creature - a white, middle-class Christian woman at that. "All the women are white, all the blacks are men, but some of us are brave," proclaimed Gloria Hull, Patricia Bell Scott, and Barbara Smith - the title of their groundbreaking 1982 book on black women's studies. ${ }^{27}$ Even though Ida Wells and Mary Church Terrell had been arguing since the turn of the twentieth century

Religious Identity in the Context of Interfaith Dialogue," Crosscurrents 62, no. 3 (Fall 2012): 360-70; and Michelle Voss Roberts, "Religious Belonging in the Multiple," Journal of Feminist Studies in Religion 26, no. 1 (Spring 2010): 43-62.

24 Simone de Beauvoir's The Second Sex, first published in French in 1949 (Le duexième sex [Paris: Galliard]; English translation by Constance Borde and Sheila Malovany-Chevallier [New York: Vintage Books, 2011]), is often identified as the early voice of the second wave. The period is generally defined as beginning in the 1960 os and continuing into the $1980 \mathrm{os}$ in the United States. A classic text of the time is Luce Irigaray's Speculum of the Other Woman, first published in France under the title Speculum de l'autre femme (Paris: Éditions de Minuit, 1974); English translation by Gillian C. Gill (Ithaca, NY: Cornell University Press, 1985).

25 Lettie Cottin Pogrebin, Deborah, Golda and Me: Being Female and Jewish in America (New York: Crown Publishing, 1991), xi.

26 See Rosemary Ruether, Sexism and God-Talk: Toward a Feminist Theology (Boston: Beacon Press, 1983); Judith Plaskow, Standing Again at Sinai: Judaism from a Feminist Perspective (San Francisco: Harper SanFrancisco, 1990); Rita M. Gross, Buddhism After Patriarchy: A Feminist History, Analysis, and Reconstruction of Buddhism (Albany, NY: State University of New York Press, 1992); and Amina Wadud, Qur'an and Woman: Rereading the Sacred Text from a Woman's Perspective (New York: Oxford University Press, 1999), based on doctoral work completed in 1989 .

27 Gloria Hull, Patricia Bell Scott, and Barbara Smith, All the Women are White, All the Blacks are Men, But Some of Us Are Brave: Black Women's Studies (New York: The Feminist Press at the City University of New York, 1982). 
that the link between sexism and racism stood at the root of white male dominance; even though women of diverse races, classes, and religions had struggled with the pain of invisibility; even though the fight for civil rights highlighted the different experience of African American bodies in America; even though Alice Walker was probably right when she famously wrote "womanist is to feminist as purple is to lavender,"28 suggesting that womanism is the richer, larger project because it addresses multiple forms of domination and makes more room for the diverse relationships that shape women's lives-white feminists like me still struggle to decenter the white experience. Similarly, Christian feminists struggle to decenter their own religious perspective.

While second-wave feminism recognized that women were not simply men in disguise, the tendency to essentialize perpetuated injustice. "Such universalizing claims about women are always false, and function oppressively to normalize particular-socially and culturally privileged—forms of feminist experience. ${ }^{29}$

Parallel progress and problems are evident in the development of interreligious learning. It increasingly recognized and dignified difference, liberating study and encounter from lowest-common-denominator equations. Dialogues were reimagined to learn about the uniqueness of each tradition. ${ }^{30}$ Just as feminist theology tried to affirm the voice and experience of women (or at least white women), these encounters attempted to affirm the voice and experience of diverse religions. Such approaches contested what Asma Barlas has called "the pervasive (and oftentimes perverse) tendency to view differences as evidence of inequality" 31

One could see a shift as the field of religious studies took shape in the 196os, distinct from theology in its non-confessional approach. Explicitly interdisciplinary and comparative, with deep study of religious difference, the field experienced a rapid expansion of degree programs and academic positions. Ninian Smart, a key figure in the popularization of such nonsectarian study, introduced a highly influential methodology that attempted to break free of Western or Christian conceptions of spiritual worldviews. Making room for

28 Alice Walker, In Search of Our Mothers' Gardens (San Diego, CA: Harcourt Brace Jovanovich, 1983), frontispiece.

29 Alison Stone, "On the Genealogy of Women: A Defense of Anti-Essentialism," in Gillis, Howie, and Munford, Third Wave Feminism, p16.

3o See, for example, Leonard Swidler and Rabbi Marc Tanenbaum, Jewish-Christian Dialogues (Washington, DC: National Council of Catholic Men and National Council of Catholic Women, 1966).

31 Asma Barlas, Believing Women in Islam: Unreading Patriarchal Interpretations of the Qur'an (Austin, TX: University of Texas Press, 2002), 5. 
nontheistic traditions, for instance, he identified doctrinal, mythological, ethical, ritual, experiential, and institutional (and later material) "dimensions" of religion. ${ }^{32}$ Similarly, Wilfred Cantwell Smith's 1962 controversial but now classic book, The Meaning and End of Religion, ${ }^{33}$ asserted that the very concept of religion was a modern Christian European invention. He proposed an alternative framework to examine the diverse "cumulative traditions" and multiple modes of expressing "faith."

The study of difference revealed additional challenges. In Orientalism, Edward Said argued that Christian privilege and its associated geopolitical power distorted perceptions of difference, leading to patronizing conceptions of the "East," making scholarship a tool of Western imperialism. ${ }^{34}$ In addition, religious studies and comparative religion often operated as though one could establish a singular Judaism, Islam, Buddhism, etc. They did not account for diversity within religious communities, or the ways lived tradition might vary from the reified "ism" of a particular religion. Although more recent scholarship has attempted to avoid such essentialism, ${ }^{35}$ pedagogy frequently still falls into these patterns. A quick scan of textbooks used to teach about religions of the world illustrates how difficult it is to capture the dynamism and diversity within each one.

In interreligious studies and engagement there is still a tendency to focus on religious traditions that are theistic, scriptural, and global, and on communities with recognizable hierarchies, clergy, and organizational structures. Leonard Swidler's pioneering work in the field illustrates the early imprint of this frame: The Journal of Ecumenical Studies (founded in 1964 as an intra-Christian endeavor and evolving to become the first academic journal to address interreligious studies) and the Dialogue Institute (founded in 1978) focused for many years on Judaism, Christianity, and Islam. His still-cited rules of interreligious dialogue are known as the "Dialogue Decalogue," a reference most evocative for faithful readers of the Bible. One of its principles is that a person must come to the table "significantly identified with a religious community," 36

32 Ninian Smart, The Religious Experience of Mankind (Upper Saddle River, NJ: Prentice Hall, 1969).

33 Wilfred Cantwell Smith, The Meaning and End of Religion (Minneapolis, MN: Fortress Press, 1964).

34 Edward W. Said, Orientalism (New York: Pantheon Books, 1978).

35 Although Smart cautioned in 1978 that scholars should pay more attention to "religion on the ground," the more essentialized approach remained the rule. See Smart, Religion and the Western Mind (Albany, NY: State University of New York Press, 1987), 50.

$3^{6}$ Leonard Swidler, "The Dialogue Decalogue: Ground Rules for Interreligious Dialogue," Journal of Ecumenical Studies 20, no. 1 (Winter 1983): 1. He later added the term 
thus potentially excluding individuals who are agnostic, interspiritual, or spiritual but not religious, and raising questions about who owns traditions. Despite increasing awareness of these complexities, the undertow of old habits lingers.

There also remains a tendency to center Christian experience. The locus of many interreligious degree programs, for example, is in Christian or historically Christian theological and divinity schools. While this development flows naturally from the historical dominance of Christianity, as well as seminaries' special interest in the "dynamic encounter between religious traditions and persons," the result is that many programs have majority Christian faculty and student bodies, curricular structures that best fit Christian learning goals, and the power dynamics of serving as host. What is a secular humanist or a student who does not subscribe to a scripture to do with the concentration on sacred texts? Similarly, preaching and leading worship are not universal roles for religious leaders, yet they remain requirements in most programs. How does "pastoral care" (even the language reflects Christian culture) change in a Hindu context, and can a classically trained Christian practical theologian incorporate it in more than token fashion?

Another example: A frequent exercise in interreligious studies involves developing a theology of religions so that students become self-aware of the terms on which they engage religious others. The analysis usually revolves around the classic trinity of pluralism, inclusivism, and exclusivismessentially Christian categories flowing from Christian questions about salvation. Even though they have been problematized for lacking sufficient nuance or capacity for diversity, the tweaks still make the most sense for a tradition that has (or had) universal aspirations. Some lifestances do not really need to create a theological account for people who orient around religion differently. ${ }^{37}$ Beyond the framing of comparative questions in Christian terms, the ongoing "norming" of Christian values remains problematic. Its tendency to privilege that which is eternal and universal, for example, marginalizes traditions

"Inter-Ideological" to make room for atheism and other orientations that might not be termed "religious."

See Paul Knitter, ed., The Myth of Religious Superiority (Ossining, NY: Orbis Books, 2005), especially Perry Schmidt-Leukel, "Exclusivism, Inclusivism and Pluralism: The Tripolar Typology-Clarified and Reaffirmed," 13-27; and Rita Gross, "Excuse Me, but What's the Question? Isn't Religious Diversity Normal?" 75-87. See also Seung Chul Kim, "How Could We Get Over the Monotheistic Paradigm for the Interreligious Dialogue?" Journal of Interreligious Studies 13 (February 2014): 20-33. 
that emphasize the temporal and particular. ${ }^{38}$ Embedded deeply in the cultural context of the United States, Christianity dominates even "secular" values; there is no neutral space for interreligious engagement. ${ }^{39}$

\subsection{Diversity}

None of these dynamics completely vanish in theory or practice, but we now shift to delineate waves whose imprints are still more recent on the shoreline, alongside the rising tide of interreligious studies as an identifiable field. "The personal is political" was a rallying cry of second-wave feminism, recognizing the connection between individual experience and larger social structures. As the claim becomes populated by the stories of diverse individuals in the third wave, real multiplicity becomes visible. We each come with our own narrative, an identity that is itself multiple and in flux, with accounts of race, class, ethnicity, culture, sexual orientation, gender, and religion. Stripping away essentialist constructions, we cannot presume the primacy of gender or religious identity, demand that an individual represent his/her entire tradition, or expect that someone's embodiment of gender or religion will be precisely like that which we have read in a book.

It takes a while for the wave of diversity to wash over these fields, a theoretical approach that presents no master narrative of oppression or experience, and no single, static view of liberation or religion. Third-wave feminism is not simply advancing more inclusive ideas of women's experience, but also exploring different methodologies. Chela Sandoval writes of a "differential consciousness" in third world feminism, one that is "vital to the generation of a next 'third wave' and provides grounds for alliance with other decolonizing movements for emancipation." ${ }^{40}$ Womanist and mujerista thought pave the way in

38 Judaism has frequently been denigrated for its more particular focus. See Anders Runesson, "Particularistic Judaism and Universalistic Christianity? Some Critical Remarks on Terminology and Theology," Studia Theologica 53 (1999): 58-6o; Jonathan Sacks, The Dignity of Difference: How to Avoid the Clash of Civilizations (London: Bloomsbury, 2002); Rosemary Radford Ruether on the "schism of particularism and universalism" in Faith and Fratricide: The Theological Roots of Anti-Semitism (Eugene, OR: Wipf and Stock, 1974), 233-39.

39 See Tracy Fessenden, Culture and Redemption: Religion, the Secular and American Literature (Princeton, NJ: Princeton University Press, 2006).

40 Sandoval, "U.S. Third World Feminism: The Theory and Method of Oppositional Consciousness in the Postmodern World," Genders 10 (1991): 4. The earliest invocation of the third wave may have been in the 1980s, when M. Jacqui Alexander, Lisa Albrecht, and Mab Segrest planned a volume, The Third Wave: Feminist Perspectives and Racism, but the publisher (New York: Kitchen Table/Women of Color Press) was struggling and the project did not come to fruition until 1994, with a broader array of editors and amended title. 
addressing manifold forms of domination, theorizing hybridity, and speaking about lo cotidiano, the significance of quotidian details in our lives. ${ }^{41}$ Queer theory also helps to deconstruct assumptions about categories of man/woman, as in Judith Butler's Gender Trouble, ${ }^{42}$ facilitating more fluid, nonbinary deliberations.

Recognizing that we are all impacted by the social construction of gender and its inequities, women's studies has been reorganized as gender studies in many schools, and its interdisciplinary foundations have deepened. ${ }^{43}$ In a 1992 article in $M s$. magazine, Rebecca Walker emphasizes alternative dimensions of the third wave; she is more conscious of generational difference and focuses on noninstitutional change, personal agency, and iconoclastic expressions of self. ${ }^{44}$ Collectively, such developments stake out a larger and more inclusive tent.

Many of these trends are reflected to some extent in interreligious studies as the field begins to develop some disciplinary maturity. Multiple ways of thinking about religious difference emerge out of each religious and nonreligious particularity, pressing the field to account for lived religion beyond the "isms" and how that shapes actual engagement. After the 1965 Immigration Act opened the doors wider to individuals from Asia, subsequent decades brought more substantial religious diversity to college campuses. As a consequence, encounters with diverse Hindu, Buddhist, Jain, and Sikh people eventually transformed perceptions of Eastern traditions from exotic, essentialized religions of faraway lands into dynamic, homegrown multiplicities. Transnational identity and cross-cultural influences add complexity to analysis. Majority and minority religious cultures necessarily shape each other, expanding thinking

Important works pointing toward third wave issues without the terminology include bell hooks, Ain't I a Woman? Black Women and Feminism (Brooklyn, NY: South End Press, 1981); Audre Lorde, Sister, Outsider (repr., 1984; New York: The Crossing Press, 2007); Gloria Anzaldua and Cherrie Moraga, eds., This Bridge Called My Back: Writings by Radical Women of Color (New York: Kitchen Table Press, 1981).

41 See Ada María Isasi-Díaz, Mujerista Theology: A Theology for the 21st Century (Maryknoll, NY: Orbis Books, 1996); Kimberlé Crenshaw, "Mapping the Margins: Intersectionality, Identity Politics \& Violence Against Women of Color," Stanford Law Review (July 1991): 1241-99; Homi Bhabha, The Location of Culture (London: Routledge, 1994). Judith Butler, Gender Trouble: Feminism and the Subversion of Identity (New York and London: Routledge, 1990).

43 See e.g., Department of Gender and Women's Studies, "History," University of California, Berkeley, accessed January 10, 2019, http://womensstudies.berkeley.edu/about/history/.

44 Rebecca Walker, "Becoming the Third Wave," Ms. 11, no. 2 (January 1992): 39-41. See also Jo Reger, ed., Different Wavelengths: Studies of the Contemporary Women's Movement (New York: Routledge, 2005); and Leslie Heywood and Jennifer Drake, Third Wave Agenda: Being Feminist, Doing Feminism (Minneapolis, MN: University of Minnesota Press, 1997). 
about hybridity. ${ }^{45}$ And, as we increasingly emphasize the individual story, it becomes clear that people speak from a lifestance rather than speaking for the whole of it. ${ }^{46}$

Encounter with postcolonial theory and its global perspective challenge theonormativity. Alongside rapidly growing religious diversity in the United States, they expand interfaith engagement beyond the "trialogue" of Judaism, Christianity, and Islam. They also prompt a critique of theological pluralism as the universal standard for religious enlightenment, with its potential to become yet another imperialist project that imposes Western values: must one affirm the sufficiency and efficacy of other lifestances, and the value of multiple paths in the world as the "new truth?"47

The field of interreligious studies and community engagement efforts are now grappling with a certain lack of diversity in their ranks. In a realignment of spiritual communities, "progressive" traditions and individuals often find more in common with each other than with conservative perspectives in their own religious group. Few people who identify as religiously conservative have been active in the field or movement. This is beginning to change, however, due to global events that demonstrate the urgency of interreligious cooperation, and a more clearly articulated distinction between theological pluralism versus the more fundamental commitment to religious pluralism as seeking understanding across lines of difference. ${ }^{48}$ As with the shift from women's studies to gender studies, recognition that all of us are impacted by the social construction of religion and the encounter with difference draws a broader range of participants into interreligious studies, including theologically

45 See E. Allen Richardson, Strangers in This Land: Religion, Pluralism and the American Dream rev. ed. (Jefferson, NC: McFarland and Co., 1988, 2010); Diana Eck, A New Religious America: How a "Christian Country" Became the World's Most Religiously Diverse Nation (New York: Harper Collins, 2002); and Robert Wuthnow, America and the Challenges of Religious Diversity (Princeton, NJ: Princeton University Press, 2005).

46 See Jennifer Howe Peace and Or Rose, eds., My Neighbor's Faith: Stories of Interreligious Encounter, Growth and Transformation (Maryknoll, NY: Orbis Books, 2012); and Mary C. Boys and Sara S. Lee, Christians \& Jews in Dialogue: Learning in the Presence of the Other (Woodstock, VT: Skylight Paths, 2006). Some textbooks for religion in America courses have become more cognizant of intrafaith dynamism and variation, e.g., Catherine Albanese, America: Religions and Religion, $5^{\text {th }}$ ed. (Belmont, CA: Wadsworth, 2012).

47 Kwok Pui-lan and Stephen Burns, Postcolonial Practice of Ministry: Leadership, Liturgy and Interfaith Engagement (Lanham, MD: Lexington Books, 2016); and Paul Knitter, "Is the Pluralist Model a Western Imposition?" in The Myth of Religious Superiority, 28-43.

48 See Nicholas M. Price, "All Nations Before God's Throne: Evangelicals in the Interfaith World," Crosscurrents 55, no. 3 (Fall 2005): 404-13; and Neil J. Young, We Gather Together: The Religious Right and the Problem of Interfaith Politics (New York: Oxford University Press, 2016). 
conservative voices. Yet the bigger tent can also complicate issues of gender and LGBTQ rights; even the question of Christian privilege in interreligious space becomes more fraught, since evangelicals experience that claim very differently from mainline Protestants and Roman Catholics.

As the academic field builds its institutional infrastructure with the creation of degree programs, the establishment of an American Academy of Religion (AAR) Interreligious and Interfaith Studies unit, an increase in dedicated journals and consortia, etc., it is simultaneously expanding the space for individuals' noninstitutional perspectives - the people who are "spiritual but not religious," who do not identify with mainstream articulations of their faiths, or who claim multiple religious belongings. ${ }^{49}$ Queer theory also helps to disrupt categories of religious identity. These more iconoclastic lifestances have begun to reshape some of the working foundations of interreligious studies. For example, what does interspirituality do to assumptions about appropriation? How do we challenge gatekeeping that marginalizes individuals who do not fit tidily inside traditions, while still recognizing the value of boundaries for theological coherence and community cohesion?

The "third wave" includes non-experts who share stories in books and blogs about their transformative encounters with religious difference. They create independent networks of people who want to build bridges. They launch crowd-funding campaigns to assist someone else's religious community in distress..$^{50}$ Misinformation abounds in some "lay" spaces, but the world of interreligious learning grows larger.

In moving from the encounter of religions to the encounter of persons, greater attention is paid to the intersections of religious difference with race, class, nationality, gender, and sexuality — with varying salience for each person and context. The result is an amazingly rich chorus of diverse voices. Yet the theoretical emphasis on diversity also has its limitations, and sometimes

49 See Robert C. Fuller, Spiritual but Not Religious: Understanding Unchurched America (New York: Oxford University Press, 2001); Manuela Kalsky and André van der Braak, eds., Open Theology 3, no. 1 (January 2017); and Catherine Cornille, ed., Many Mansions? Multiple Religious Belonging and Christian Identity (Eugene, OR: Wipf and Stock, 2002).

5o See Ranya Idliby, Susanne Oliver, and Priscilla Warner, The Faith Club: A Muslim, a Christian a Jew - Three Women Search for Understanding (New York: Simon and Schuster, 2006); Sisterhood of Salaam Shalom, accessed January 10, 2019, https://sosspeace .org/; and Muslim campaigns to rebuild black churches and Jewish cemeteries attacked by vandals, e.g., Launchgood, "Rebuild with Love: Rebuild Black Churches and Support Victims of Arson Across the South," accessed January 10, 2019, https://www .launchgood.com/project/rebuild_with_love_rebuild_black_churches_support_victims_of_arson_across_the_south\#/; https://www.launchgood.com/project/muslims_ unite_to_repair_jewish_cemetery\#/. 
becomes mired in identity politics, undercutting possibilities for connection. The intersections can be challenging to navigate. For example, many Jewish anti-racism activists are angry about the plank in the Black Lives Matter platform that accuses Israel of genocide against the Palestinian people and endorses the Boycott, Divestment and Sanctions movement against Israel. Feminist and womanist voices sometimes reflexively view hijab and niqab as oppressive, despite Muslim women's divergent accounts. Interreligious space can become constricted, as people refuse to sit with others who will not stand with them. We need a more capacious language of and platform for encountering difference, one that can transcend the potential for division in diversity.

\subsection{Intersubjectivity}

Suggestions that a fourth wave of feminism has begun often highlight online communication and activism that have created national and transnational social networks. This wave is queer, sex and body-positive, anti-misandrist, and trans-inclusive. It tries to live into the ecology of commitments that intersectional theory brought to the fore. Continuing the micropolitics of the third wave, it challenges the sexism that appears daily in television, advertising, media, and the multiple contexts of women's lives - with the added power of generating instant social media campaigns. ${ }^{51}$ From calling out the epidemic of drug-facilitated sexual assault to Pantsuit Nation (a Facebook group born during the 2016 presidential campaign, with its perplexing match-up of the first woman to head a major-party ticket and a candidate who spoke about the privilege of groping women at will), fourth-wave feminism tries to harness the power of women's stories through the internet.

Some of these qualities appear in the world of interreligious learning and engagement. Certainly, cyberspace has become an increasingly important venue for such activity, for good and for ill. Many people get an increasing percentage of their information (and misinformation) about religion from the internet/ social media, and even individuals who live in homogeneous communities can "meet" people who orient around religion differently.

51 See the varied emphases among these respective online postings: Ealasaid Munro, "Feminism: A Fourth Wave?" PSA Blog, accessed January 10, 2019, http://www.psa.ac.uk/insightplus/feminism-fourth-wave; Martha Rampton, "Four Waves of Feminism," Pacific University, October 25, 2015, accessed January 10, 2019, http://www.pacificu.edu/about-us/ news-events/four-waves-feminism; Jennifer Baumgardner, "Is there a Fourth Wave? Does it Matter?" Feminist.com, 2011, accessed January 10, 2019, http://www.feminist.com/resources/artspeech/ genwom/baumgardner2o11.html; and Kristen Sollee, "6 Things to Know about Fourth Wave Feminism," Bustle, October 31, 2015, accessed January 10, 2019, http://www.bustle.com/articles/119524-6-things-to-know-about-4th-wave-feminism. 
Recognized contexts for multifaith encounters continue to multiply. The Interfaith Youth Core (IFYC) capitalizes on the remarkable diversity on college campuses to nurture student-led integrative learning projects with participants who actively seek engagement with religious difference. These efforts are fashioning a new generation of interfaith leaders. ${ }^{22}$ Businesses have become more conscious of the need for religious accommodation and interreligious competencies. Advertisements feature Muslim actors and representatives to counter the impact of Islamophobic rhetoric. Arts, families, media-all are increasingly recognized as critical sites of interreligious connection. ${ }^{53}$ Pedagogical tools such as the Pluralism Project's case study initiative (since 2008) use religion as a central organizing paradigm to highlight ways in which difference complicates every facet of our lives, even when people come with good intentions.

There is another development within the fourth wave of womanist/ feminist/mujerista thought that may be even more transformational for interreligious studies - namely, its serious attempt to wrestle with the implications of identity politics. "The elusiveness of this category of 'woman' raised questions about the nature of identity, unity and collectivity," and revealed that a movement hoping for unity based on female identity was too fragile. ${ }^{54}$ Emphasis on identity draws some in from the margins but it also risks fracturing the body politic..$^{5}$

One way to address this problem is to emphasize intersubjectivity, solidarity (communidad in mujerista theology), and relationality. These concepts contest old notions that agency derives only from autonomy. What we identify as boundaries are often permeable and mutually constitutive; competing identities are increasingly recognized as intersectional. Nira Yuval-Davis speaks of a process of rooting and shifting: ${ }^{56}$ rooting in our particular identity, but also recognizing how the partiality of our positions and selves leads us to need one

52 See Eboo Patel, Interfaith Leadership: A Primer (Boston: Beacon Press, 2016). The IFYC was established in 2002. In the 1980 os and 1990s a few campus chaplains and faculty led the way, establishing multifaith councils, interfaith discussion groups, and resources to reimagine interreligious learning and engagement on campus. See Victor Kazanjian and Peter Laurence, Education as Transformation: Religious Pluralism, Spirituality and a New Vision for Higher Education in America (New York: Peter Lang, 2000).

53 Kate McCarthy began to explore diverse contexts of interfaith engagement in Interfaith Encounters in America (New Brunswick, NJ: Rutgers University Press, 2007).

54 Gillis, Howie, and Munford, Third Wave Feminism, xxi.

55 See Linda Martin Alcoff, Michael Hames-Garcia, Satya Mohanty, and Paula M. L. Moya, eds., Identity Politics Reconsidered (New York: Palgrave Macmillan, 2006).

56 Nira Yuval-Davis, Gender \& Nation (Thousand Oaks, CA: SAGE Publications, 1997). 
another. Thus we shift in diverse and provisional alliances where, in true dialogue with difference, we experience other ways of being.

Interreligious studies similarly lifts up encounters with difference as catalysts to deepen our own spiritual formation. We cease to theorize each other and instead meet each other in our messy multiplicity in a coformative process. Intersubjectivity incorporates theologies that are already afloat. As a Jew, I hear echoes of Martin Buber, who showed us the irreducible relation of I and Thou, and Emmanuel Levinas, who explained through the biblical Hebrew construct "hineni-here I am" how the "I" is constituted in response and responsibility to another. ${ }^{57}$ Others might hear Buddhist teacher Thich Nhat Hanh's exposition on interbeing. ${ }^{58}$ These ideas deepen our accountability to one another as they illuminate our interdependency and magnify our capacity for empathy.

Recognizing both the limitations and privileged perspective of our own experience, a dialectic that feminist theorist Donna Haraway calls "situated knowledge,"59 opens another avenue for interreligious relationship-the recovery of epistemological humility as a theological position. ${ }^{60}$ Interreligious studies, like gender studies, is learning to embrace ambiguity. Coming to terms with irreducible difference yields not just a debate about conflicting truths, but a dialogical necessity. This inexorable logic makes the field of interreligious studies an urgent requirement.

The directions of these waves press for a different pedagogical model, one that does not treat interreligious programs primarily as a division of religious studies. As with women's studies, having the conversation only with those already predisposed to attend to the relevant issues from a particular perspective is of limited value. Expanding diversity illuminates the need for interreligious literacy in multiple professions and contexts. Yet the experience I can share unfolds in a seminary context, where interreligious studies cultivates the knowledge, attitudes and skills religious leaders need to productively navigate a spiritually diverse world.

57 Martin Buber, I and Thou, trans. Walter Kaufmann, (repr., 1923; New York: Touchstone, 1971); and Emmanuel Levinas, Otherwise than Being or Beyond Essence, trans. Alphonso Lingis (Berlin: Kluwer Academic Publishers, 1981), 114, 142-43, 152, 185, 199.

$5^{8}$ Thich Nhat Hanh, Interbeing: Fourteen Guidelines for Engaged Buddhism (Berkeley, CA: Parallax Press, 1987).

59 Donna Haraway, "Situated Knowledges: The Science Question in Feminism and the Privilege of Partial Perspective," Feminist Studies 14, no. 3 (Autumn 1988): 575-99.

6o See James L. Heft, Reuven Firestone, and Omid Safi, eds., Learned Ignorance: Intellectual Humility among Jews, Christians, and Muslims (New York: Oxford University Press, 2011). 


\section{Part 2: Interreligious Studies at Chicago Theological Seminary: Institutional Transformation in Motion}

\subsection{Background}

Over thirty years ago, Hebrew Bible scholar André LaCocque instituted a Center for Jewish and Christian Studies at Chicago Theological Seminary (CTS), ${ }^{61}$ convinced that Christians could not understand their faith without understanding the Judaisms out of which it grew. The Center was comprised primarily of a doctoral program and related academic conferences, but the commitment embedded itself in the institution. Chicago Theological Seminary was among the first Christian seminaries to emphasize Jesus as a Jew, to teach the Hebrew Bible as the people and faith of Israel, to set interreligious understanding into its "Mission and Commitments" statement, and to grapple with the polemical and supersessionary nature of Christian scripture, language, and theology. Adding Islamic Studies to the Center's focus, LaCocque then organized the first conference in the United States about women in Islam with an emerging cadre of Muslima scholars.

The work was also intended, "in recognition of the toll taken by religious divisions in our world," to foster "better understanding and collaboration among religious traditions, paying particular attention to cooperation among Christianity, Judaism, and Islam toward the end of realizing the aims of the prophetic traditions." 62

These goals formed the core of the institution's stake in interreligious education: to prepare religious leaders/teachers who better understand their own religious identity, and who build bridges across religious difference to effect positive social transformation. In many ways the project typified a secondwave phenomenon, making space for difference with only rudimentary theoretical tools to excavate the complexity of Christian history, power, and the contemporary context.

Since that time, CTs endowed a chair in Jewish Studies, hired adjunct or visiting faculty with expertise in diverse traditions, and expanded the Center for Jewish, Christian, and Islamic Studies (JCIS) to include a rich variety of co-curricular and public programs (workshops, lectures, artistic presentations, holiday celebrations, worship, symposia, and social justice projects). The

$61 \quad$ The Chicago Theological Seminary is affiliated with the United Church for Christ, with students, staff, and faculty from diverse religious traditions.

62 "Mission and Commitments," Chicago Theological Seminary, last accessed November 6, 2017, www.ctschicago.edu/about/philsophy/. The paragraph was updated in 2017 to include a broader array of lifestances and recognition of Christian privilege. 
Center increasingly worked with members of the diverse Chicago community in a variety of partnerships to make its mark on the public square.

While CTS was very supportive of these efforts, the projects were often too dependent on the initiative of a few individuals. Broader institutional buy-in for interreligious studies unfolded during the seminary's strategic planning process. We began to "audit" various internal structures - calendar, chapel, the language of our program areas and mission statement, etc.- to challenge Christian privilege and name its particularity. For example, guidelines for chapel leaders were revised to encourage facilitators to identify their religious particularity (leading also to greater recognition of intragroup diversity), and to be sensitive to the potential presence of people who stand outside the tradition. Leaders are not told to seek the lowest common denominator; spiritual hospitality does not mean erasure of identity. During convocations and commencements we try to express the diverse voices of our community and find more inclusive language, without diminishing the clarity of particular expressions. Achievement of these goals remains uneven, however, and it is still "chapel"a normatively Christian gathering.

Chicago Theological Seminary established a requirement for advancedlevel coursework in a religious tradition other than one's own, expanded course offerings, and introduced a master's degree in Interreligious Engagement as well as concentrations for existing degree programs. In an effort to avoid the structural biases of Christian institutions, the degree was designed to be customizable.

Beginning in 2014, we admitted as part of our incoming class a multifaith cohort committed to sustained conversation and collective work, exploring the intersections of theological education, interreligious engagement, social justice, and sustainability. The three-year project, entitled ECOmmunity, crystallized after faculty addressed two substantive issues in our interreligious efforts. First, the enterprise is too theoretical if there is insufficient religious diversity within the institution. Second, although there had frequently been a few non-Christians studying at CTS, the isolated nature of their experience meant that they had to do all the work of adaptation (of Christian language, culture, curriculum). We needed a student cohort of mutual support, one with enough heft to help transform the institution. We subsequently recruited several talented groups of Christian, Muslim, Hindu, secular humanist, and transreligious individuals, with differing racial, national, gender, sexual, and class identities, and representing some range along the religiously progressiveconservative spectrum.

Incremental change generally reveals its limitations, however. Although we prepared one masters-level program to foster religious diversity without the 
vestiges of Christian normativity that generally inhabit theological degrees, many of our non-Christian students need the MDiv or traditional MA for their professional pursuits. For now, we are merely tweaking the other programs, relying too much on the initiative of students and advisors to navigate a way through with petitions for alternative requirements. Also, each lifestance that is new to our community challenges our capacity to provide adequate learning inside that tradition, and to responsibly integrate it within our broader curriculum and culture.

Within these institutional constraints, and still buffeted by all the tidal forces at work, in recent years our pedagogy of interreligious studies and engagement has developed in ways that reflect the third and fourth waves. As we reimagine how this work unfolds at CTS and beyond, JCIS and ECOmmunity have been absorbed by a new enterprise, the InterReligious Institute, that is more fully integrated throughout the institution. Below, I discuss three elements - coformation, complexity, and intersectionality — that have shaped our growth through this ongoing process.

\section{2 "Coformation"}

Advantages of theological education in a religiously diverse setting are manifold: Students become more conscious of their own religious particularity and more adept at narrating their journey within it, gaining perspective to view their tradition from outside as well as within. Utilizing each tradition's capacity for self-critique and development, students refine their ideas and identities through the sharpening lens of encounter. Their agency is magnified by relationship with one another. They come to know other ways of being and experience their limits not only as boundaries but as meeting places. ${ }^{63}$ They recognize how their beliefs take shape in a complex, intersubjective, multifaith and nonfaith world.

The ECOmmunity cohort began as an exercise in coformation, ${ }^{64}$ growing from consciousness of our intersubjectivity and informed by the teaching

63 See Rachel Adler, Engendering Judaism: An Inclusive Theology and Ethics (Boston: Beacon Press, 1999), 114-38.

64 Coformation theory emerges out of therapeutic and sociological contexts, such as the work of Bette Katsekas, "Holistic Interpersonal Mindfulness: Activities and Application of Coformation Theory," Journal of Clinical Activities, Assignments and Handouts in Psychotherapy Practice 2, no. 3 (2002): 1-12; Jules Falquet, "La règle du jeu. Repenser la coformation des rapports sociaux d sexe, de class et de 'race," in Elsa Dorlin, ed., Sexe, race et classe (Paris: Presses Universitaires de France, 2009), pp. 177-97. Jennifer Peace utilizes the term in interreligious engagement, "Coformation Through Interreligious Learning," 
philosophy of Paulo Freire: we educate one another, in communion, in the context of living in this world. ${ }^{65}$ Coformation unfolds in sharing personal stories as well as grappling together with the challenges and opportunities of seminary education. The process asks students to be vulnerable to one another, to trust that the tensions will yield new insights, and that the journey together through the wilderness will enable them to live more fully into their religious/ philosophical commitments and their human potential. "The lived experience of on-the-ground, co-inhabited cultural diversity has functioned as a fluid, omnipresent, alternative and global social imaginary always-in-the-making." 6

Students work to cultivate common ground, and to respect substantive differences in the ways individuals orient around religion. While celebrated as expressions of the vital, vibrant diversity of human life, differences can also lead to conflict; consequently, students learn to make space for difficult conversations. They practice with each other, participate in courses and programs that model this capacity, and undergo training in conflict transformation. The recent controversy over "safe space" on college campuses unfortunately suggests a binary choice; interreligious studies can present a middle ground of supported space for uncomfortable but essential encounters.

Questions of power, privilege, and oppression cannot be excised from our understanding of the ways in which religion impacts people's lives, and how interactions among religions shape history. They inundate the public square, the campus, and the very programs that try to name them. One cohort facilitated a workshop on "Power, Privilege, and Oppression in an Interreligious Context" for our major spring conference. We prod students to explore these issues not only "out there," but also in our own institution, grappling with the asymmetry of resources and representation, competing priorities, and manifold claims of race, class, gender, sexuality, and religion. This challenging terrain strengthens the sinews of their lifestance formation.

ECOmmunity's intimate learning cohort can be adapted in numerous ways, such as the interfaith living communities established on several college campuses. "Living in close quarters with those of different faiths can teach students first-hand about different beliefs and values, dietary practices, and ways of

Colloquy 20, no. 1 (Fall 2011): 24-26,http://www.ats.edu/uploads/resources/publicationspresentations/colloquy/colloquy-2011-fall.pdf.

65 Paulo Freire, Education for Critical Consciousness (New York: Seabury Press, 1973).

66 Cinthya Martinez, "The East," in Elisa Faco and Irene Lara, eds., Fleshing the Spirit: Spirituality and Activism in Chicana, Latina and Indigenous Women's Lives (Tucson, AZ: University of Arizona Press, 2014), 27. 
practicing and worshipping." 67 This kind of space naturally creates room for difficult conversations, but the requisite attitude and skill set can also be cultivated with other types of experiential learning. Key to coformation is peer-topeer interaction, developing intersubjective sensitivity, and learning to be accountable to one another.

Coformation unfolds in relationship with the institution as well. While theological education is expected to have significant influence on the spiritual formation of students, the presence of substantial religious diversity also helps to (re)form CTs, cultivating deeper consciousness in course construction, instructional language, food, calendars, sacred space, worship, and every other seminary activity. ECOmmunity students expanded their impact on the institution in their regular interactions with peers and professors, and in creating tools such as an "Interfaith Firsts" video designed to spark conversation at CTS - simultaneously shaping their own identity as interreligious leaders. The impact was not always intentional. In revamping our "Middler Review" process (a self-assessment instrument used in the MDiv program to determine suitability for the profession) to work for non-Christians, we stumbled upon a far more compelling exploration of spiritual formation.

Because there are now students who arrive without any background in Christianity, faculty members are having to readjust how certain subjects are taught. One professor fielded the question "Who is Paul?" on the first day of her "History of Christian Thought" course. Although she recognized that answering such a basic question on a key Christian figure would likely benefit some Christian students as well (who would not dare to ask the question), the experience highlighted new pedagogical challenges in teaching graduate students from an increasingly broad range of backgrounds. Even so, coformation theory insists that we often learn more about or even become ourselves as we explain ourselves to others.

Institutional transformation is gradual. Many faculty members, staff, and students have figured out how to navigate a multifaith context of Christianity, Judaism, and Islam (reflecting our longer-term efforts), but this does not easily expand to include other faiths and secular traditions, or to acknowledge individuals who do not fit in any box. Students find some courses to be well designed for teaching in an interreligious setting, with much of the previously covert diversity now finding fruitful expression, but other courses still operate

67 Interfaith Youth Core, "Interfaith Communities in Residence Life," accessed October 13, 2019, https://www.ifyc.org/sites/default/files/u4/ResLife.pdf. Macalester, Colgate University, Rollins College, and the University of Southern California offer interfaith communities as part of their Residential Life programs. 
as if everyone in the room is Christian. In the latter case, non-Christian students must continually engage in acts of translation to make their learning meaningful, and seek out religiously diverse voices on their own. The shared struggle of students and the seminary over how to catalyze institutional change is also part of our coformation; to achieve maximal impact, interreligious efforts cannot be siloed.

\subsection{Complexity}

Despite the theoretical complexity that has taken hold as interreligious studies becomes an academic field of study, numerous programs and individuals still pursue the work as if sympathetic learning about religious difference constitutes its single objective - as if only the first two waves had washed ashore. Given ongoing tensions emanating from religious diversity, it may seem unwise to complicate the normative value of coexistence that remains an anchor for the field. Yet even such convictions should be problematized as they are pursued. How might a commitment to theological pluralism be a Western or a liberal imposition? How do we maintain the principles that undergird the interreligious project, while recognizing them as situated knowledge rather than objective truths? ${ }^{68}$

Thus, while our core course in interreligious engagement includes multifaith literacy and understanding, dialogue, and peacebuilding skills, it also tries to complicate the narrative based on the conviction that a more sophisticated exploration will yield more resilient progress. Students explore intragroup diversity, the politics of representation, theorizing difference, issues of appropriation and ownership, etc. Questions about the "theology/philosophy of religions" are informed by postcolonial and feminist theory, to decenter Christian and Western (and male) experience.

Students interrogate the presumption that "interreligious" means we are dealing with stable and equal definable entities, with established institutions, communities, clergy, deities, and scripture. They recognize issues of power and privilege; intersections of identity around race, class, gender, sexuality, and religion; ${ }^{69}$ how our religious narratives impact each other; diverse contexts

68 See Janet Jakobsen, "Ethics After Pluralism," in Courtney Bender and Pamela Klassen, eds., After Pluralism: Reimagining Religious Engagement (New York: Columbia University Press, 2010), 31-58.

69 See Debra Mubashshir Majeed, "Womanism Encounters Islam," in Stacey Floyd-Thomas, ed., Deeper Shades of Purple: Womanism in Religion and Society (New York: New York University Press, 2006), 38-57; and Laurel Schneider, "What Race is Your Sex?" in Jennifer Harvey, Karin A. Case, and Robin Hawley Gorsline, eds., Disrupting White Supremacy from Within: White People on What We Need to Do (Cleveland, OH: Pilgrim Press, 2004), 142-62. 
and modes of engagement; ${ }^{70}$ and the impact of religion in the public square. ${ }^{71}$ When students undertake study about lifestances other than their own, they must include experiential learning and resist essentializing. They are then required to convey the learning to a peer who stands inside that tradition, discerning what it means to be accountable to one another.

We try to sustain complexity through comparable critical engagement in other courses, such as the deliberately de-essentialized "Living, Breathing Judaisms"; Bible courses that examine hermeneutical lenses and social location in the history of exegesis; and a "Women's Voices: Ruether, Lorde, Plaskow, and Wadud" seminar that explores gender, sexual, and racial justice issues with an interreligious, intersectional lens. These courses are increasingly emblematic of the broader curriculum, from pastoral care to constructive theology, with diverse religious voices.

Community engagement is essential to the field because it illuminates ways to move beyond essentialism or reified tradition toward connection with the fluid, polymorphous, interactive spiritual patterns of human believing, behaving, and belonging. Through biweekly cohort meetings, specialized workshops, co-curricular programs, group projects, and opportunities for students to involve themselves beyond the boundaries of the seminary in structured field education experiences and independent initiatives, ECOmmunity attempted to nurture a sophisticated appreciation for the concrete challenges of interfaith encounter. JCIS served as a living laboratory for students, although we were not always successful in empowering them to develop community partnerships and design/implement programs.

A variety of factors constrain the pursuit of a sophisticated pedagogyriptides that run counter to the flow of the waves. Since many Christian students come with little experience or understanding of religious difference, for

70 In addition to the common modes of engagement such as dialogue/study, worship, service-learning, and social justice work, the course explores the critical role of media, arts, cyberspace, family life and campus engagement.

71 See Barbara A. McGraw, "Introduction to America's Sacred Ground," in Barbara A. McGraw and Jo Renee Formicola, eds., Taking Religious Pluralism Seriously: Spiritual Politics on America's Sacred Ground (Waco, TX: Baylor University Press, 2005), 1-26; David Hollinger, "Religious Ideas: Should They Be Critically Engaged or Given a Pass?" Representations 101 (Winter 2008): 144-54; and Eboo Patel, "Religious Pluralism in the Public Square," in Sally Steenland, ed., Debating the Divine: Religion in $27^{\text {st }}$ Century American Democracy (Washington DC: Center for American Democracy, 2008), 16-25; available online at Center for American Progress, June 24, 2008, accessed January 10, 2019, http://www.americanprogress.org/issues/2008/o6/debating_the_divine.html; and Diana Eck, "Prospects for Pluralism," Journal of the American Academy of Religion 75, no. 4 (December 2007): $743-73$. 
example, students of other lifestances admit to feeling occasionally exoticized when those who are not in the cohort express sincere but inept interest. In some ways, we must continually start again at the beginning when new students arrive. Limited time constricts the depth of learning, and lack of established metrics to assess the impact of interreligious studies and engagement, in the academy and the public square, all hamper development of best practices. In seminary contexts, limited funds also reduce the capacity for transformation: ECOmmunity materialized only when a grant allowed us to engage a full-time visiting professor in Islamic studies. While we make efforts to recognize the full spectrum of lifestances, we can afford to develop expertise and resources in only a few, unfortunately often perpetuating bias toward the "Abrahamic" religions.

\subsection{Intersectionality}

The developing pedagogy of interreligious studies at CTS is designed to nurture the ecology of our commitments to counter systemic racism, sexism, heteronormativity, poverty, environmental destruction, religious discrimination, and other oppressions. In response, ECOmmunity was born to operate at the intersections of theological education, interreligious engagement, social justice, and sustainability. Unpacking the last of these items begins to reveal their interdependence.

The ecological component is significant, given our move to a "Gold" LEEDcertified building, alongside a growing interest in lifestance responses to environmental crises and creation care. We understand sustainability, however, both as an environmental concern and an organismic goal for human communities. We embrace the fundamental conviction that diversity is more sustainable and life-producing than monoculture, and affirm its theistic translation: unity in Heaven is manifest through diversity on earth.

Decentering Christian experience in theological education dovetails with decentering human experience on the planet, and our intersectional approach to human community parallels interactions within ecosystems. Nurturing this type of deep ecological consciousness, ECOmmunity focused on interdependent relationships: the distinct backgrounds and gifts of cohort members, diverse aspects of the project, different centers and programs of Стs, synergetic relationship with many institutions and groups whose objectives overlap with our own-all of these form the connective tissue that holds the social body together and fashions stronger communities.

A social justice pedagogy is not merely appropriate in the progressive, politically engaged context of CTS; it is fundamental to interreligious studies' normative claims of cooperation and appreciation. In the wave of "diversity," the 
multiplicity and dynamism of identity was increasingly recognized; we all bear notions of race, class, gender, sexual orientation, nationality, etc. in shifting balances and contexts. In the current of "intersubjectivity," it becomes evident that efforts to challenge discrimination and resolve conflict can be successful only if we engage the intersectionality of identities and oppressions. More than embodied solidarity or collective agency, we recognize our immutable interconnection. We also recognize the unique ways in which individual identities combine in our social context: just as a "woman" has historically been viewed differently depending on her skin color, so too are religious experiences often different depending on other factors of identity. Theory is tested repeatedly over against the singular lives of a diverse student body as we become accountable to each other's story, still being written.

Interreligious studies at С TS sets religion at these crossroads without claiming primacy. We require all Master of Divinity students to take a course called "Living into our Commitments and Creating Social Change." The course explores critical discourses around race, gender, sexuality, class, and religion so that we develop a shared language-making religious difference an integral part of students' thinking about human community and contesting the siloing of interreligious engagement. Conversely, courses that emphasize interreligious learning must reckon with all the other vehicles of difference at the intersection, both in the syllabus and in the classroom.

Intersectionality is also a focus in applied contexts. For example, JCIS put substantial energy into two national conferences sponsored by Стs that were ostensibly about race, "Selma at 50: Still Marching" and "Mapping a Movement." Integration of voices from multiple faith traditions brought vital perspective to the work, directed attention to the ways in which each social issue touches upon others, and enhanced conference participants' networking power for making change.

Despite these efforts, and despite broad support for the interreligious project, it is difficult to eradicate tensions around the scarcity of resources. Competing priorities around gender, race, sexuality, class, and religion vie for time, people, money, and attention. Thus the InterReligious Institute (IRI) is designed to be profoundly intersectional and interdisciplinary, drawing together the worlds of activism and the academy, theological education and other fields/professions, and our diverse aspects of identity. It also moves beyond the "Abrahamic" traditions. More closely integrated in the workings of the seminary, the project is building strong structures for deliberation and collective leadership.

The IRI seeks to operate on three platforms. InterThink develops metrics and disseminates best practices in interfaith and intersectional community 
efforts. InterFace implements leadership training for individuals in diverse fields that require interreligious and other multicultural skills. InterChange is the seminary's living laboratory for creative pedagogies and public programs directed at social transformation. Chicago Theological Seminary hopes to pour much of what it has learned along the way into this new mold.

Do these paths have broader implications for Interreligious Studies beyond the parameters of CTs? Thomas Tweed, in his 2008 book Crossing and Dwelling, speaks of "itineraries" as a metaphor for theories, playing with the term's semantic range. An itinerary is a proposed route, but it is also the embodied journey along that route and an account of the travels told from a particular position..$^{72}$ The discussion of pedagogy as it is evolving at СтS is an itinerary: while delineating one perspective that unfolds within a single context, it also offers ideas to explore, essentials to pack, cautions for the road, and snapshots for comparison as fellow travelers join in documenting the developing pedagogy of interreligious studies.

Returning to the metaphorical universe of waves, what can we say about the currents of interreligious studies, given that people and institutions find themselves in different parts of the sea? Because the work at CTS grew out of broader social forces and disciplinary developments, many elements appear to be germane across contexts. Of course, each effort finds its own starting point along the shore and wades into the waters in its own way. None of the waves have completed their work, even as the sea continues to generate new ones. While it is difficult to establish fixed standards and goals for the field of interreligious studies and engagement, we can help each other ask the right questions. The self-critical capacities of most lifestances and the academy have driven the tidal forces that carried us along through the waves of equality, difference, diversity, and intersubjectivity — and they will continue to press forward toward new horizons.

\section{Bibliography}

Adler, Rachel. Engendering Judaism: An Inclusive Theology and Ethics. Boston: Beacon Press, 1999 .

Albanese, Catherine. America: Religions and Religion. $5^{\text {th }}$ ed. Belmont, CA:Wadsworth, 2012.

72 Thomas A. Tweed, Crossing and Dwelling: A Theory of Religion (Cambridge, MA: Harvard University Press, 2008) also attempts to redress the tendency to describe lifestances as static and independent. 
Alcoff, Linda Martin, Michael Hames-Garcia, Satya Mohanty, and Paula M. L. Moya, eds. Identity Politics Reconsidered. New York: Palgrave Macmillan, 2006.

Anzaldua, Gloria, and Cherrie Moraga, eds. This Bridge Called My Back: Writings by Radical Women of Color. New York: Kitchen Table Press, 1981.

Bailey, Cathryn. "Making Waves and Drawing Lines: The Politics of Defining the Vicissitudes of Feminism." Hypatia 12, no. 3 (June 1997): 29-45.

Barlas, Asma. Believing Women in Islam: Unreading Patriarchal Interpretations of the Qur'an. Austin, TX: University of Texas Press, 2002.

Barrows, John Henry, ed.. The World's Parliament of Religions, Vol. 2. Chicago, IL: Parliament Publishing Company, 1893.

Baumgardner, Jennifer. "Is there a Fourth Wave? Does it Matter?" Feminist.com, 2011. Accessed January 10, 2019. http://www.feminist.com/resources/artspeech/genwom/ baumgardner2011.html.

Bhabha, Homi. The Location of Culture. London: Routledge, 1994.

Blumfeld, Warren, Khyati Joshi, and Ellen Fairchild, eds. Investigating Christian Privilege and Religious Oppression in the United States. Rotterdam: Sense Publishers, 2008.

Boys, Mary C. and Sara S. Lee. Christians \& Jews in Dialogue: Learning in the Presence of the Other. Woodstock, VT: Skylight Paths, 2006.

Buber, Martin. I and Thou. Translated by Walter Kaufmann. Reprint. New York: Touchstone, 1923, 1971.

Butler, Judith. Gender Trouble: Feminism and the Subversion of Identity. New York; London: Routledge, 1990.

Cantwell Smith, Wilfred. The Meaning and End of Religion. Minneapolis, MN: Fortress Press, 1964.

Cherry, Conrad. Hurrying Toward Zion. Bloomington, IN: Indiana University Press, 1995 .

Chicago Theological Seminary. "Mission and Commitments." Last accessed November 6, 2017. http://www.ctschicago.edu/about/philsophy/.

Cohen, Naomi. Jews in Christian America: The Pursuit of Religious Equality. New York: Oxford University Press, 1992.

Cornille, Catherine, ed. Many Mansions? Multiple Religious Belonging and Christian Identity. Eugene, OR: Wipf and Stock, 2002.

Crenshaw, Kimberlé. "Mapping the Margins: Intersectionality, Identity Politics \& Violence Against Women of Color." Stanford Law Review (July 1991): 1241.

De Beauvoir, Simone. The Second Sex, translated by Constance Borde and Sheila Malovany-Chevallier. New York: Vintage Books, 2011.

Dinnerstein, Leonard. Antisemitism in America. New York: Oxford University Press, 1994. 
Eck, Diana. "Prospects for Pluralism," Journal of the American Academy of Religion 75, no. 4 (December 2007): 743-76.

Eck, Diana. A New Religious America: How a "Christian Country" Became the World's Most Religiously Diverse Nation. New York: Harper Collins, 2002.

Eck, Diana. "Parliament of Religions, 1893." The Pluralism Project, Harvard University. Accessed January 10, 2019. pluralism.org/encounter/historical-perspectives/parli ament-of-religions-1893/.

Falquet, Jules. "La règle du jeu. Repenser la coformation des rapports sociaux d sexe, de class et de 'race." In Elsa Dorlin, ed. Sexe, race et classe. Paris: Presses Universitaires de France, 2009.

Fessenden, Tracy. Culture and Redemption: Religion, the Secular and American Literature. Princeton, NJ: Princeton University Press, 2006.

Freire, Paulo. Education for Critical Consciousness. New York: Seabury Press, 1973.

Fuller, Robert C. Spiritual but Not Religious: Understanding Unchurched America. New York: Oxford University Press, 2001.

Gilligan, Carol. In a Different Voice. Cambridge, MA: Harvard University Press, 1982.

Gillis, Stacy, Gillian Howie, and Rebecca Munford, eds. Third Wave Feminism: A Critical Exploration. 2nd ed. New York: Palgrave Macmillan, 2007.

Gross, Rita M. Buddhism After Patriarchy: A Feminist History, Analysis, and Reconstruction of Buddhism. Albany, NY: State University of New York Press, 1992.

Hanh, Thich Nhat. Interbeing: Fourteen Guidelines for Engaged Buddhism. Berkeley, CA: Parallax Press, 1987.

Haraway, Donna. "Situated Knowledges: The Science Question in Feminism and the Privilege of Partial Perspective." Feminist Studies 14, no. 3 (Autumn 1988): 575-99.

Harris, Grove. "Pagan Involvement in the Interfaith Movement: Exclusions, Dualities and Contributions." Crosscurrents 55, no. 1 (Spring 2005): 66-76.

Hedges, Paul. "Interreligious Studies." In Anne Runehov and Lluis Oviedo, eds. Encyclopedia of Sciences and Religions. Dordrecht: Springer Netherlands, 2013.

Heft, James L., Reuven Firestone, and Omid Safi, eds. Learned Ignorance: Intellectual Humility among Jews, Christians, and Muslims. New York: Oxford University Press, 2011.

Heywood, Leslie and Jennifer Drake. Third Wave Agenda: Being Feminist, Doing Feminism. Minneapolis, MN: University of Minnesota Press, 1997.

Hollinger, David. "Religious Ideas: Should They Be Critically Engaged or Given a Pass?" Representations 101 (Winter 2008): 144-54.

hooks, bell. Ain't I a Woman? Black Women and Feminism. Brooklyn, NY: South End Press, 1981.

Howe Peace, Jennifer and Or Rose, eds. My Neighbor's Faith: Stories of Interreligious Encounter, Growth and Transformation. Maryknoll, NY: Orbis Books, 2012. 
Hull, Gloria, Patricia Bell Scott, and Barbara Smith. All the Women are White, All the Blacks are Men, But Some of Us Are Brave: Black Women's Studies. New York: The Feminist Press at the City University of New York, 1982.

Idliby, Ranya, Susanne Oliver, and Priscilla Warner. The Faith Club: A Muslim, a Christian a Jew-Three Women Search for Understanding. New York: Simon and Schuster, 2006.

Irigaray, Luce. Speculum de l'autre femme. Paris: Éditions de Minuit, 1974. English translation by Gillian C. Gill. Ithaca, NY: Cornell University Press, 1985.

Isasi-Díaz, Ada María. Mujerista Theology: A Theology for the 21st Century. Maryknoll, NY: Orbis Books, 1996.

Jakobsen, Janet. "Ethics After Pluralism." In Courtney Bender and Pamela Klassen, eds., After Pluralism: Reimagining Religious Engagement, 31-58. New York: Columbia University Press, 2010.

Kalsky, Manuela and André van der Braak, eds. Open Theology 3 no. 1 (January 2017).

Katsekas, Bette. "Holistic Interpersonal Mindfulness: Activities and Application of Coformation Theory." Journal of Clinical Activities, Assignments and Handouts in Psychotherapy Practice 2, no. 3 (2002): 1-12.

Kazanijan, Victor and Peter Laurence. Education as Transformation: Religious Pluralism, Spirituality and a New Vision for Higher Education in America. New York: Peter Lang, 2000.

Kim, Seung Chul. "How Could We Get Over the Monotheistic Paradigm for the Interreligious Dialogue?" Journal of Interreligious Studies 13 (February 2014): 20-33.

Knitter, Paul, ed. The Myth of Religious Superiority. Ossining, NY: Orbis Books, 2005.

Levinas, Emmanuel. Otherwise than Being or Beyond Essence. Translated by Alphonso Lingis. Berlin: Kluwer Academic Publishers, 1981.

Lorde, Audre. Sister, Outsider. Reprint. New York: The Crossing Press, 1984, 2007.

Martinez, Cinthya. "The East." In Elisa Faco and Irene Lara, eds., Fleshing the Spirit: Spirituality and Activism in Chicana, Latina and Indigenous Women's Lives, 21-22. Tucson, AZ: University of Arizona Press, 2014.

Mauzawa, Tomoko. The Invention of World Religions: Or, How European Universalism Was Preserved in the Language of Pluralism. Chicago: University of Chicago Press, 2005 .

McCarthy, Kate. Interfaith Encounters in America. New Brunswick, NJ: Rutgers University Press, 2007.

McGraw, Barbara A. “Introduction to America's Sacred Ground.” In Barbara A. McGraw and Jo Renee Formicola, eds., Taking Religious Pluralism Seriously: Spiritual Politics on America's Sacred Ground, 1-26. Waco, TX: Baylor University Press, 2005.

Meyer, Michael. Response to Modernity: A History of the Reform Movement in Judaism. Detroit, IL: Wayne State University, 1995. 
Mikva, Rachel. "Six Issues that Complicate Interreligious Studies and Engagement." In Eboo Patel, Jennifer Peace, and Noah Silverman, eds., Toward a Field of Interfaith Studies, 124-136. Boston: Beacon Press, 2018.

Mubashshir Majeed, Debra. "Womanism Encounters Islam." In Stacey Floyd-Thomas, ed., Deeper Shades of Purple: Womanism in Religion and Society, 38-53. New York: New York University Press, 2006.

Munro, Ealasaid. “Feminism: A Fourth Wave?” PSA Blog. Accessed January 10, 2019. http://www.psa.ac.uk/insight-plus/feminism-fourth-wave; http://www.pacificu .edu/about-us/news-events/four-waves-feminism.

Paskow, Judith. Standing Again at Sinai:Judaism from a Feminist Perspective. San Francisco: Harper SanFrancisco, 1990.

Patel, Eboo. "Religious Pluralism in the Public Square." In Sally Steenland, ed., Debating the Divine: Religion in $21^{\text {st }}$ Century American Democracy, 16-27. Washington DC: Center for American Democracy, 2008. Available online. Accessed January 10, 2019. http://www.americanprogress.org/issues/2008/o6/debating_the_divine.html.

Patel, Eboo. Interfaith Leadership: A Primer. Boston: Beacon Press, 2016.

Pateman, Carole. The Sexual Contract. Cambridge, MA: Polity Press, 1988.

Peace, Jennifer. “Coformation Through Interreligious Learning." Colloquy 20, no. 1 (Fall 2011): 24-26.

Pogrebin, Lettie Cottin. Deborah, Golda and Me: Being Female and Jewish in America. New York: Crown Publishing, 1991.

Preston, Charles S. "Wach, Radhakrishan, and Relativism." In Christian Wedemeyer and Wendy Doniger, eds., Hermeneutics, Politics and the History of Religions, 79-100. New York: Oxford University Press, 2010.

Price, Nicholas M. "All Nations Before God's Throne: Evangelicals in the Interfaith World." Crosscurrents 55, no. 3 (Fall 2005): 404-13.

Pui-lan, Kwok and Stephen Burns. Postcolonial Practice of Ministry: Leadership, Liturgy and Interfaith Engagement. Lanham, MD: Lexington Books, 2016.

Radford Reuther, Rosemary. "The Schism of Particularism and Universalism." In Faith and Fratricide: The Theological Roots of Anti-Semitism. Eugene, OR: Wipf and Stock, 1974 .

Radford Reuther, Rosemary. Sexism and God-Talk: Toward a Feminist Theology. Boston: Beacon Press, 1983 .

Rampton, Martha. "Four Waves of Feminism." Pacific University, October 25, 2015. Accessed January 10, 2019. http://www.pacificu.edu/about-us/news-events/fourwaves-feminism.

"Reform Judaism: The Pittsburgh Platform." Jewish Virtual Library. Accessed January 10, 2019. http://www.jewishvirtuallibrary.org/jsource/Judaism/pittsburgh_program .html. 
Reger, Jo, ed. Different Wavelengths: Studies of the Contemporary Women's Movement. New York: Routledge, 2005.

Richardson, E. Allen. Strangers in This Land: Religion, Pluralism and the American Dream, revised edition. Jefferson, NC: McFarland and Co., 1988, 2010.

Runesson, Anders. "Particularistic Judaism and Universalistic Christianity? Some Critical Remarks on Terminology and Theology." Studia Theologica 54, no. 1 (2000): $55^{-75}$.

Sacks, Jonathan. The Dignity of Difference: How to Avoid the Clash of Civilizations. London: Bloomsbury, 2002.

Said, Edward W. Orientalism. New York: Pantheon Books, 1978.

Sandoval, Chela. "U.S. Third World Feminism: The Theory and Method of Oppositional Consciousness in the Postmodern World." Genders 10 (1991): 1-24.

Schneider, Laurel. "What Race is Your Sex?” In Jennifer Harvey, Karin A. Case, and Robin Hawley Gorsline, eds., Disrupting White Supremacy from Within: White People on What We Need to Do, 142-62. Cleveland, OH: Pilgrim Press, 2004.

Smart, Ninian. Religion and the Western Mind. Albany, NY: State University of New York Press, 1987 .

Smart, Ninian. The Religious Experience of Mankind. Upper Saddle River, NJ: Prentice Hall, 1969 .

Sollee, Kristen. "6 Things to Know about Fourth Wave Feminism." Bustle, October 31, 2015. Accessed January 10, 2019. http://www.bustle.com/articles/119524-6-things-toknow-about-4th-wave-feminism.

Stone, Alison. "On the Genealogy of Women: A Defense of Anti-Essentialism." In Gillis, Howie, and Munford, Third Wave Feminism, 85-96. London: Palgrave McMillan, 2004.

Stopes-Roe, Harry. "Humanism as a Life Stance." New Humanist 103, no. 2 (October 1988): 19-21.

Suomala, Karla. "Complex Religious Identity in the Context of Interfaith Dialogue." Crosscurrents 62, no. 3 (Fall 2012): 360-70.

Swidler, Leonard and Rabbi Marc Tanenbaum. Jewish-Christian Dialogues. Washington, DC: National Council of Catholic Men and National Council of Catholic Women, 1966 .

Swidler, Leonard. “The Dialogue Decalogue: Ground Rules for Interreligious Dialogue," Journal of Ecumenical Studies 20, no. 1 (Winter 1983): 1-4.

Talvacchia, Kathleen T. Critical Minds and Discerning Hearts: A Spirituality of Multicultural Teaching. St. Louis, MO: Chalice Press, 2003.

Truth, Sojourner. “Ain't I a Woman?” Ohio Women's Rights Convention, Akron OH 1851. Fordham University Modern History Sourcebook. Accessed January 10, 2019. https:// sourcebooks.fordham.edu/mod/sojtruth-woman.asp. 
Tweed, Thomas A. Crossing and Dwelling: A Theory of Religion. Cambridge, MA: Harvard University Press, 2008.

Voss Roberts, Michelle. "Religious Belonging in the Multiple." Journal of Feminist Studies in Religion 26, no. 1 (Spring 2010): 43-62.

Wadud, Amina. Qur'an and Woman: Rereading the Sacred Text from a Woman's Perspective (New York: Oxford University Press, 1999).

Walker, Alice. In Search of Our Mothers' Gardens. San Diego, CA: Harcourt Brace Jovanovich, 1983 .

Walker, Rebecca. "Becoming the Third Wave." Ms. 11, no. 2 (January 1992): 39-41.

Wollstonecraft, Mary. A Vindication of the Rights of Women. Reprint. New York: A.J. Matsell, 1793,1833 .

Wuthnow, Robert. America and the Challenges of Religious Diversity. Princeton, NJ: Princeton University Press, 2005.

Young, Neil J. We Gather Together: The Religious Right and the Problem of Interfaith Politics. New York: Oxford University Press, 2016.

Yuval-Davis, Nira. Gender \& Nation. Thousand Oaks, CA: SAGE Publications, 1997.

Ziolkowski, Eric J., ed. A Museum of Faiths: Histories and Legacies of the 1893 World's Parliament of Religions. New York: Oxford University Press, 1993. 